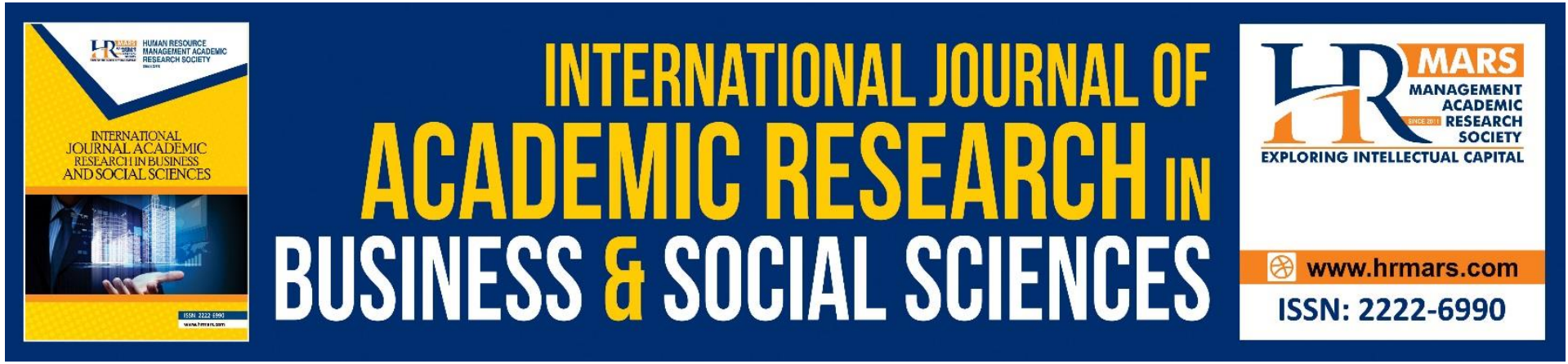

\title{
The Future of the Retail Industry by Implementing Omnichannel Marketing Strategy in the Republic of North Macedonia
}

Gjorgjina Sherovska, Ilijana Petrovska

To Link this Article: http://dx.doi.org/10.6007/IJARBSS/v11-i8/10450

DOI:10.6007/IJARBSS/v11-i8/10450

Received: 12 June 2021, Revised: 14 July 2021, Accepted: 10 August 2021

Published Online: 17 August 2021

In-Text Citation: (Sherovska \& Petrovska, 2021)

To Cite this Article: Sherovska, G., \& Petrovska, I. (2021). The Future of the Retail Industry by Implementing Omnichannel Marketing Strategy in the Republic of North Macedonia. International Journal of Academic Research in Business and Social Sciences, 11(8), 1948-1968.

\section{Copyright: @ 2021 The Author(s)}

Published by Human Resource Management Academic Research Society (www.hrmars.com)

This article is published under the Creative Commons Attribution (CC BY 4.0) license. Anyone may reproduce, distribute, translate and create derivative works of this article (for both commercial and non-commercial purposes), subject to full attribution to the original publication and authors. The full terms of this license may be seen at: http://creativecommons.org/licences/by/4.0/legalcode

Vol. 11, No. 8, 2021, Pg. 1948 - 1968

Full Terms \& Conditions of access and use can be found at http://hrmars.com/index.php/pages/detail/publication-ethics 


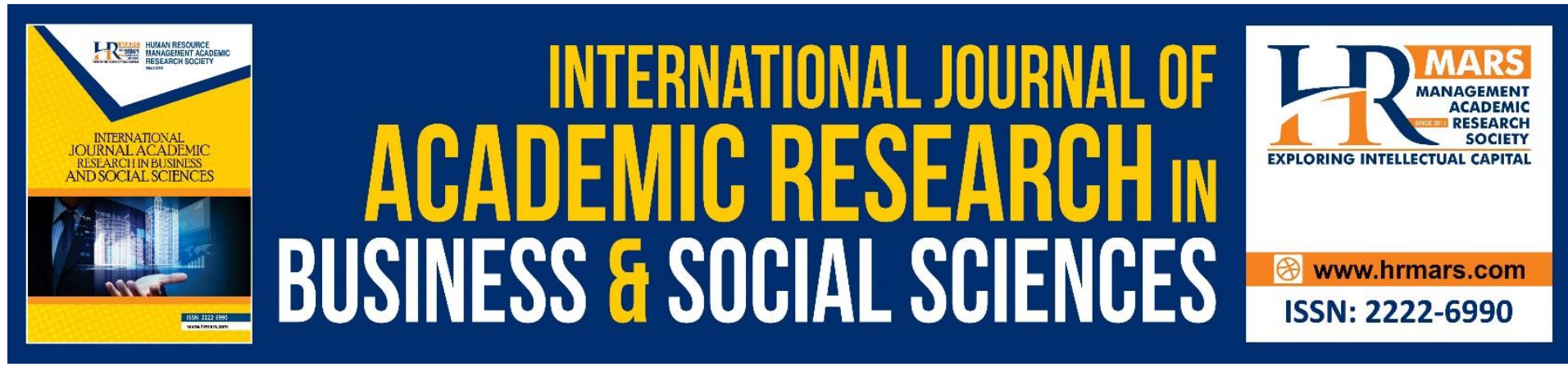

\title{
The Future of the Retail Industry by Implementing Omnichannel Marketing Strategy in the Republic of North Macedonia
}

\author{
Gjorgjina Sherovska \\ PhD Student, School of Business Economics and Management, University American College \\ Skopje, Republic of North Macedonia \\ Email: gsherovska@yahoo.com
}

\section{Ilijana Petrovska}

PhD, Professor, School of Business Economics and Management, University American College Skopje, Republic of North Macedonia

\begin{abstract}
There have been significant changes evident across the retail sector over the last 20 years, which have been primarily influenced by technological advancements. These changes have forced many retailers to rethink their business models. Driven by those global advances in technology and changes in consumer buying behaviour, brick-and-mortar retailers are being forced to become omnichannel retailers subsequently bringing fundamental changes to consumer engagement, brand perspective, and price decision-making processes. This calls for new metrics for evaluating retail performance. The methodology used was a quantitative approach with a questionnaire including different types of sub-industries that are under the main industry of retail and their top executives as responders, reaching responsiveness of 100 respondents conducted online, during the period of January to February 2021 in Republic North of Macedonia. The analysis was conducted using the statistical program R Statistical Software. Responders responded to a questionnaire providing results on how omnichannel marketing impacts the retail industry by exploring through factor analysis, the two factors, profitability and customer engagement with multiple observed variables which have similar patterns of responses since they are all associated with a latent. The omnichannel research framework reported here will help guide research in this area.
\end{abstract}

Keywords: Omnichannel Marketing, Retail Industry, Profitability, Customer Engagement

\section{Introduction}

Significant changes have been evident across the retail sector over the last 20 years, primarily influenced through technological advancements that have transformed the experience of shopping both from a business perspective and from the customer point of engagement explain Jain and Werth (2019). The technological impact is firmly connected with omnichannel 
marketing, as it is pointed out by Rigby et al (2012) explaining that innovations in retailing are changing consumer expectations of the shopping experience. Technological developments have helped change the nature of customer-retailer interactions, giving rise to new shopping behaviours says Grewal et al (2017). This omnichannel strategy brings opportunity and enjoyment to the customer experience and enables customers to undertake the buying process through their own method and approach, which is most convenient for them emphasizes Lee et al (2018). Customer responses have increased immensely following these innovations explain Qazi et al (2017), which can be seen in online sales growth for retailing organizations throughout the past decade. However, there is limited research around customers' perceptions of omnichannel marketing, thereby generating a need for further investigation as to whether this new approach being adopted by retailers can lead to changes in profitability via the customer engagement coming from the customers themselves.

\section{Literature and Research Approach}

In an omnichannel context, it is fundamental to broaden the channel scope by integrating multiple customer touchpoints as Verhoef (2015b) states. Many studies have found that technological advancements are causing a significant impact on how customer lifestyles are beginning to influence retailing strategies explain Zhang and Zhao (2019). This poses a massive challenge for many retailers, especially regarding how to deliver consistent service while simplifying the customer's life as much as possible. To do this, many organizations have utilized online and mobile shopping platforms to create various interactions between the customer and the purchase of goods. Because most customers navigate between numerous channels and touchpoints before making a purchase. A hundred different customers will most likely have a hundred different paths to purchase, emphasizing the need for seamless integration of all channels and a consistent presence throughout each step of the purchasing lifecycle. The model developed by Manser et al. (2017) will be taken into consideration for the creation of such valuable touchpoints in this thesis especially because the effects that are affecting omnichannel marketing are widely considered.

Figure 1: Omnichannel IMC Framework: Touchpoints, Engagement and Profitability

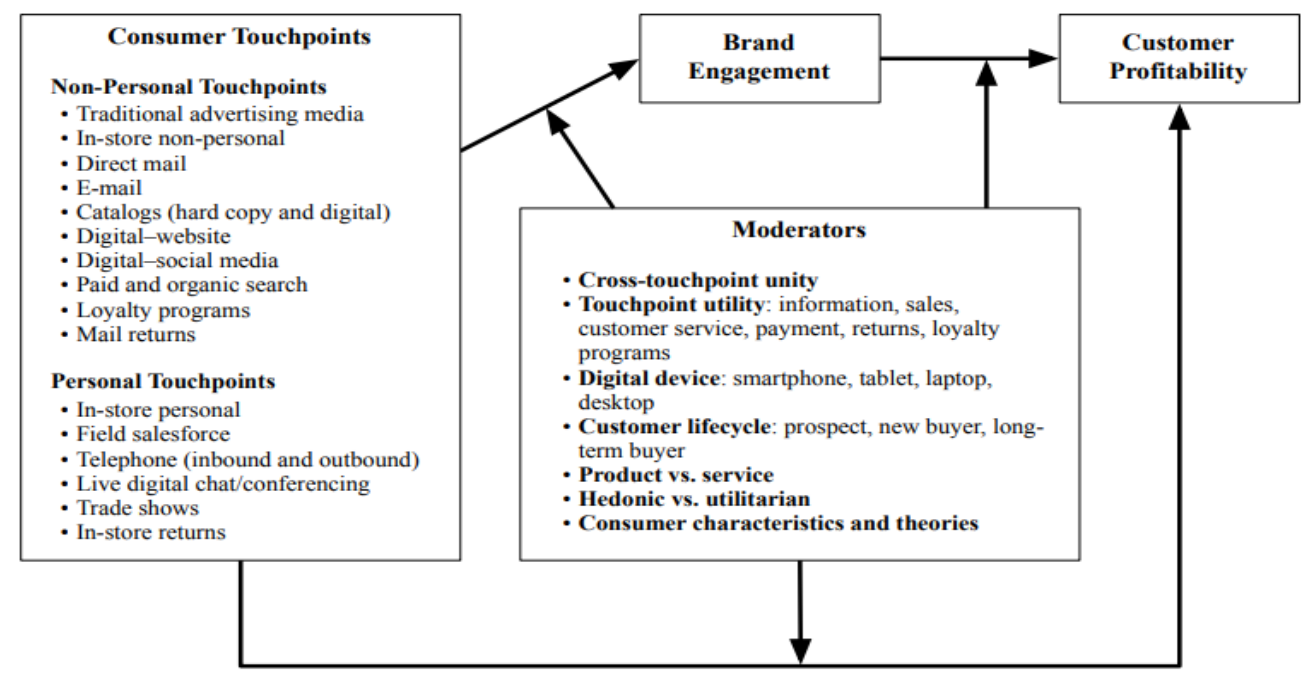

Source: Manser et al (2017). Omnichannel marketing, integrated marketing communications and consumer engagement: A research agenda. Journal of Research in Interactive Marketing, DOI: 10.1108/JRIM-08-2016-0091. 
The activities that can be performed in each of these stages have changed due to the integration of the mobile channel and a transition to omnichannel retailing. It is therefore expected that as retailers pursue omnichannel strategies, businesses will need to be reorganized and managed in different ways than before. On the other side, consumer-brand engagement has a wide array of consequences, which can be categorized into brand effects, product effects, consumer effects, content effects, and market effects stress Manser et al., (2016). The evolution from a multichannel to an omnichannel perspective requires the assessment of customer profitability, not as a summation of the profitability of each channel, but as an aggregation of all touchpoints. In this way, the integrative power of customer touchpoints offers greater insight than touchpoint-by touchpoint profitability assessment emphasizes Verhoef et al. (2015). Although, consumer-brand touchpoints may impact engagement metrics, in the end, the long-term success of a firm's marketing efforts depends on profitability measures such as conversions, margins, return of investment, sales, customer retention, and customer lifetime value say Li et al., (2014).

Figure 2: Initial research developed model

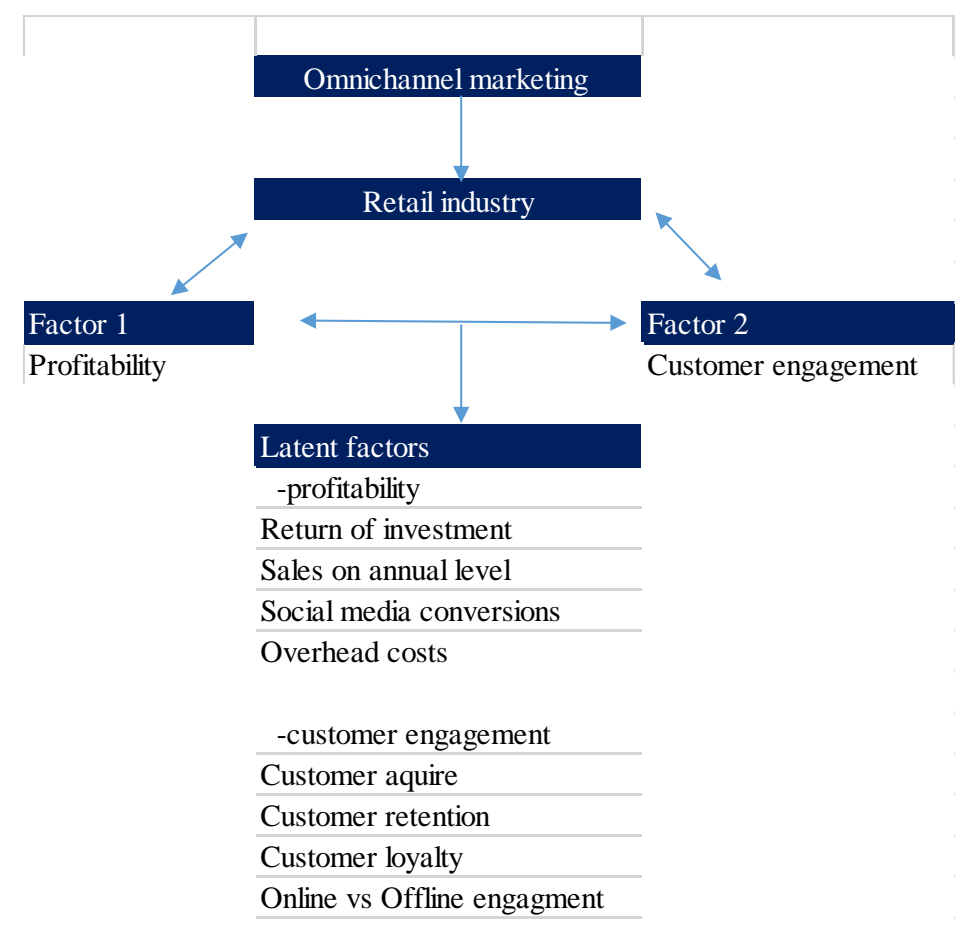

Source: developed by author

From the model in Figure 2 which was developed with in this thesis, results were explored in terms of how omnichannel marketing impacts the retail industry by exploring through factor analysis, the two factors, profitability and customer engagement with multiple observed variables which have similar patterns of responses since they are all associated with a latent. As well as how they influenced omnichannel marketing and its impact on the overall corporate strategy. Extracting and summarizing the model in Figure 3 as a more in-depth model that explained the profitability along with the customer engagement as well as its direct influence between those having omnichannel marketing as a moderator in that relationship, the following model was developed

Figure 3: In depth research developed model 


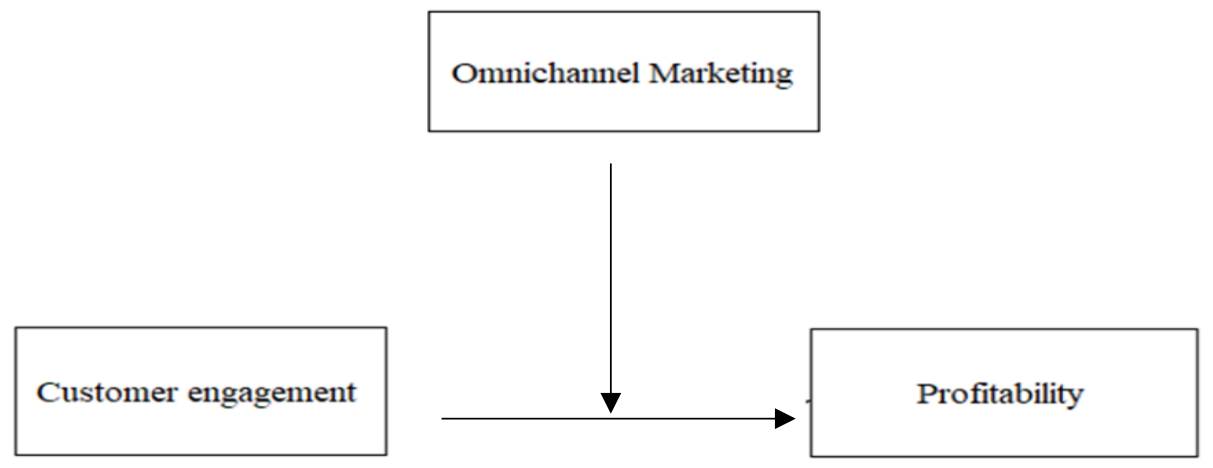

Source: developed by author

As mentioned in terms of measurement of this model apart from the profitability, the other two indicators are perception and are usually measured with a quantitative method using the Likert scale. Because the Likert scale is a set of statements (items) offered for a real or hypothetical situation under study. Participants were asked to show their level of agreement (from strongly disagree to strongly agree) with the given statement (items) on a metric scale, Singh (2006) explains. The basic assumption behind perception scales is that it is possible to uncover a person's internal state of beliefs, motivation, or perceptions by asking them to respond to a series of statements point out Fraenkel and Wallen, (1996), and Likert items are the most common response formats used in perception scales. Customer engagement and omnichannel marketing are higher-order constructs for that reason those two indicators will be part of the questionnaire. For this purpose of investigation, factor analysis was used in order to present the elements of the moderator and the independent variables.

\section{Methodology}

As outlined above, omnichannel marketing within the retailing sector has recently become a well-established field of research. However, the literature and evidence on how customers perceive it is sparse. Therefore, in order to identify what factors, determine the way in which customer satisfaction is increased through online retailing, the intention was to explore and critique various research methods in order to grasp a diverse amount of information on this topic in order to achieve the best result for the research area. The methodology used for the main research was conducted through a quantitative approach with a questionnaire. The questionnaire for this research includes different types of sub-industries that are under the main industry of retail and their top executives as responders, reaching responsiveness of 100 respondents conducted online, during the period of January to February 2021 in Republic North of Macedonia. The analysis was conducted using the statistical program R Statistical Software. Responders responded to a questionnaire providing results on how omnichannel marketing impacts the retail industry by exploring through factor analysis, the two factors, profitability and customer engagement with multiple observed variables which have similar patterns of responses since they are all associated with a latent.

\section{Discussion of Results Demographics}

Most respondents were male (55\%); most were aged between 30 and 49 years old, and most had a level of education above a master's degree (98\%). Most were either senior or middle management in their company (96\%); most had been an employee over 3-4 years (65\%). Most 
respondents (79\%) said their company had between 10-49 (38\%) and 50-249 (41\%) employees; almost a third (30\%) said their company was a medium-large business in terms of revenue, with another quarter $(26 \%)$ saying theirs was a medium-small business. Almost twothirds (63\%) said their marketing communication was outsourced. Most said their company's annual revenue was 5-10 million denars (51\%), and most (52\%) said their company's annual net profit margin was either 1-5 million denars (27\%) and 5-10 million denars (25\%). (see Table 1, Appendix 2)

\section{Customer Engagement Brand Loyalty}

Figure 1, Appendix 2 displays the distribution of agreement with items from the Brand Loyalty (BL) section of the Customer Engagement questionnaire. All respondents agreed that customers could find and purchase their products/services (BL1). Most agreed (99\%) that customers had an interactive, creative experience with their brand (BL2). Most believed (96\%) that customers could share reviews of their products/services with other customers through all channels (BL3). Most agreed (81\%) that customers were willing to pay a higher price for their brand over other brands (BL4).

\section{Customer and Prices}

Figure 2, Appendix 2 displays the distribution of agreement with items from the Customer and Prices (CP) section of the Customer Engagement questionnaire. Most agreed (95\%) that they had established reasonable prices for the offered products/services (CP1). Most also affirmed (99\%) that they offered good value for the price we set (CP2). Over $90 \%$ said that they used special offers to raise a customer's interest and influence the purchase of our products/services versus competitors' products (CP3). Three-quarters agreed (74\%) that their company's prices were the same offline as well as online (CP4).

\section{Customer Retention}

Figure 3, Appendix 2 displays the distribution of agreement with items from the Customer Retention (CP) section of the Customer Engagement questionnaire. Almost 75\% said that they had a loyalty card that provides exclusive discounts and enables our customers to come back and purchase again (CR1). Most agreed (88\%) that the atmosphere inside their retail store was always pleasant CR2). Two-thirds felt (68\%) that sensitivity to the environment and social responsibility activities' contribution to the corporate image were important in terms of customer retention (CR3). Almost $90 \%$ believed that, in the case of online orders, the trust that the customer's product would be shipped was important for the retention of customers (CR4).

\section{Traditional Marketing}

Figure 4, Appendix 2 displays the distribution of agreement with items from the Implementing traditional marketing as part of the engagement (TM) section of the Customer Engagement questionnaire. Over $80 \%$ agreed that their retail store gave complete information about brands, promotions, and services to its consumers (TM1). Most agreed (85\%) that they provided an adequate policy of refunds and exchanges (TM2). More than three-quarters $(77 \%)$ shared that their store maintained a good relationship with the consumers by sending greetings and special offers on occasions (TM3). Most believed (87\%) that they were present in traditional media, such as TV, radio, newspapers, magazines, flyer, etc. (TM4). 


\section{Customer Buying Process}

Figure 6, Appendix 2 displays the distribution of agreement with items from the Customer Buying Process (CB) section of the Customer Engagement questionnaire. Close to $75 \%$ said that they adapted the selling behavior using different arguments depending on each customer need and knowledge of the product (CB1). Most agreed (74\%) that the employees of their retail stores were efficient and reliable (CB2). Close to $90 \%$ felt that the brand reputation played an important role in the buying process of the customers (CB3). Over $80 \%$ agreed that their communication with their customers was completely transparent and honest (CB4).

\section{Overall Customer Engagement}

The overall customer engagement score was calculated as the average of the agreement to all subscale items: Brand loyalty, Customer and Prices; Customer Retention; Implementing Traditional Marketing; and Customer-Buying Process. The overall customer engagement scores ranged between with a low of 3.3 and a high of 4.6 , with an average value of 4.07 (sd $=0.265)$.

\section{Omnichannel Marketing}

Figure 5, Appendix 2 displays the distribution of agreement with items from the Implementing omnichannel marketing as part of the engagement (OM) section of the Customer Engagement questionnaire. Almost all agreed (98\%) their store was present on most social platforms with active participation (OM1). Most (80\%) also said that they had synergetic management of the channels and customer touchpoints geared toward optimizing the holistic experience (OM2). Over $80 \%$ noted that they frequently organized online activities for stimulating the customers to act (OM3). Close to $75 \%$ agreed that offering suggestions according to customers' shopping preferences at the online store was important for customer engagement (OM4). Similarly, most agreed (86\%) shared that they regularly interacted with the customers and provided good customer care (OM5). Almost two-thirds believed that Increasing the number of purchase channels might create sub-optimization and harmful competition between us and various channels (OM6). Most (89\%) felt that, with their touchpoints, they could trigger full customer interaction (OM7). Most (85\%) agreed that they were present through all channels: Internet-based media, such as social networks, emails, websites, pop-up advertisement, mobile marketing, etc. (OM8). Most agreed (90\%) that they provided seamless experiences through all online channels (OM9).

\section{Factor Analysis}

Parallel analysis suggested that there were between four latent factors underlying the responses to the omnichannel marketing section (see Figure 8, Appendix 2)

To identify the combination of items related to those four factors, exploratory factor analysis was performed using a varimax rotation, miners, and 100 iterations. The four factors cumulatively explained $49 \%$ of the variation in responses. OM7-9 loaded into one factor called Multiple Online Presence, which explained the largest proportion of variation in responses (16\%). OM1-3 loaded into another factor called Synergized Online Activities. OM4 and 5 were loaded into factor Regular Customer Interaction. And OM6 was the only variable associated with Purchase Channels. Together, these four factors explained almost $50 \%$ of the variation in responses to the omnichannel marketing sub-scale. (See Table 1, Appendix 2) 


\section{Customer Engagement, Omnichannel Marketing, and Company Profitability}

Moderation analyses were conducted to determine whether omnichannel marketing scores significantly moderated the relationship between customer engagement and company profitability. Company profitability was proxied by two variables: annual revenue, and annual net profit.

\section{Annual Revenue}

Figure 9, Appendix 2 illustrates that there was no significant correlation between annual revenue $(A R)$ and customer engagement (CE; $r=0.035, p=0.45$ ), nor with omnichannel marketing (OM; $r=0.035, p=0.733$ ). Results of multiple regression (see Table 3 ) revealed that there was no significant moderation effect of omnichannel marketing on the relationship between customer engagement and the company's annual revenue $(F(3,88)=0.221, p=0.882)$ as the interaction effect of omnichannel marketing and customer engagement was not statistically significant $(t=-0.169, p=.866)$.

\section{Annual Net Profit}

Figure 9, Appendix 2 illustrates that there was no significant correlation between annual net profit (ANP) and customer engagement (CE; $r=0.15, p=0.152$ ), nor with omnichannel marketing (OM; $r=0.07, p=0.695$ ). Results of multiple regression (see Table 4) revealed that there was no significant moderation effect of omnichannel marketing on the relationship between customer engagement and the company's annual net profit $(F(3,88)=0.878$, $\mathrm{p}=0.455)$, as the interaction effect of omnichannel marketing and customer engagement was not statistically significant $(t=-0.743, p=.459)$.

\section{Conclusion}

The key to omnichannel success is to understand the customer by analyzing his lifestyle, habits, and demands, then to provide him with the seamless shopping experience that will diminish the wall between offline and online with the use of technological innovations. The outcome will be, the brands will have a long-term positive impact on sales, customer loyalty, and potential. As results indicate, it can be concluded that return of investment has a great impact as well in the profitability of the retails considering the implementation of omnichannel marketing as a strategy considering that most of the companies, retailers were on the low medium level of annual revenue and annual net profit margin. Although trough the perception of the retails they do believe their customer have interactive creative experiences with their brand, as they offer good value for the prices they set, including special offers to raise a customer's interest and influence the purchase of our products/services versus competitors' according to the moderation analyses that was conducted to determine whether omnichannel marketing scores significantly to moderate the relationship between customer engagement and company profitability, results illustrated that there was no significant correlation between annual revenue (AR) and customer engagement nor with omnichannel marketing. Kumar (2013) propounds the notion of Customer Engagement that is slated to benefit not only the customers by offering them a superior value proposition, but also the company through the assurance of a steady stream of profits. While retailers believe that they have synergetic management of the channels and customer touchpoints geared toward optimizing the holistic experience. That includes a strong affirmation for the usage of loyalty cards, from the literature it can be pointed out that customer loyalty leads to an increase in both sales and profitability as Chi (2005) says. Even if an organization gains its 
customer's loyalty, some of them accord nothing in terms of profitability and it may become unable to retain those loyal customers. In a word, for an organization to achieve success, it should be able to take possession of its own loyal and profitable customers, in order to be able to retain them, stresses Kangu et al., (2017). Contrary to the fact that most of them believe increasing the number of purchase channels might create sub-optimization and harmful competition between themself and various channels. The perception is that they are both presents in traditional and digital marketing segments and through those channels and touchpoints, they could trigger full customer interaction. This is positive because traditional mass marketing channels are considered part of the omnichannel strategy and therefore, also require synergetic management. In addition, the omnichannel environment places increasing emphasis on the interplay between channels and brands, as Verhoef et al., (2015) state. Thus, in comparison to other multiple channel strategies, customers receive added benefits such as information visibility, cost savings, or convenience. Because in this case, the channels are managed together, the perceived interaction is not with the channel, but rather the brand [which provides additional benefits for the customer. The retailer's company profitability was proxied by two variables: annual revenue, and annual net profit. Results of a multiple regression revealed that there was no significant moderation effect of omnichannel marketing on the relationship between customer engagement and the company's annual revenue as the interaction effect of omnichannel marketing and customer engagement was not statistically significant. Also, there was no significant correlation between annual net profit (ANP) and customer engagement with omnichannel marketing. Results of a multiple regression revealed that there was no significant moderation effect of omnichannel marketing on the relationship between customer engagement and the company's annual net profit (as the interaction effect of omnichannel marketing and customer engagement was not statistically significant.

\section{Limitations and Future Research Lines}

There were two important limitations in this study to future lines of research The first one is an actual in-depth analysis of the companies done on the field with one-on-one interviews that will be based on facts taken from the reports presented to the researcher, with confidentiality It would be interesting to replicate the study with customers included for evaluation of predefined retailers, taken into account. A further limitation stems from the fact that the information is limited to the North Republic of Macedonia. Future research could validate the study in other countries where omnichannel is widely integrated into the marketing strategy of the companies, differently or that have different sociodemographic environments. Additionally, future studies could supplement the current model presented.

\section{Reference}

Fraenkel, J., \& Wallen, N. (1996). How to design and evaluate research in education. New York: McGraw-Hil

Grewal, D., Roggeveen, A., Sisodia, R., \& Nordfält, J. (2017). Enhancing Customer Engagement Through Consciousness. Journal of Retailing, 93(1), 55-64. DOI: 10.1016/j.jretai.2016.12.001

Jain, S., \& Werth, D. (2019). Correction to: $\mathrm{HCl}$ in Business, Government and Organizations. $\mathrm{HCl}$ In Business, Government And Organizations. Ecommerce And Consumer Behavior, C1-C1. DOI: 10.1007/978-3-030-22335-9_26 
Lee, Z., Chan, T., Chong, A., \& Thadani, D. (2019). Customer engagement through omnichannel retailing: The effects of channel integration quality. Industrial Marketing Management, 77, 90-101. DOI: 10.1016/j.indmarman.2018.12.004

Li, Y., Liu, H., Lim, E., Goh, J., Yang, F., \& Lee, M. (2018). Customer's reaction to cross-channel integration in omnichannel retailing: The mediating roles of retailer uncertainty, identity attractiveness, and switching costs. Decision Support Systems, 109, 50-60. DOI: 10.1016/j.dss.2017.12.010

Manser Payne, E., Peltier, J., \& Barger, V. (2017). Omni-channel marketing, integrated marketing communications and consumer engagement. Journal Of Research In Interactive Marketing, 11(2), 185-197. DOI: 10.1108/jrim-08-2016-0091

Qazi, A., Tamjidyamcholo, A., Raj, R., Hardaker, G., \& Standing, C. (2017). Assessing consumers' satisfaction and expectations through online opinions: Expectation and disconfirmation approach. Computers In Human Behavior, 75, 450-460. DOI: 10.1016/j.chb.2017.05.025

Rigby, D. (2011). The Future of Shopping. Retrieved: 5 August 2021, from https://hbr.org/2011/12/the-future-of-shopping

Singh, Y. (2006). Fundamental of research methodology and statistics. New Delhi: New Age International.

Verhoef, P., Kannan, P., \& Inman, J. (2015). From Multi-Channel Retailing to Omni-Channel Retailing. Journal Of Retailing, 91(2), 174-181. DOI: 10.1016/j.jretai.2015.02.005

Zhang, L., \& Zhao, H. (2019). Personal value vs. luxury value: What are Chinese luxury consumers shopping for when buying luxury fashion goods?. Journal Of Retailing And Consumer Services, 51, 62-71. DOI: 10.1016/j.jretconser.2019.05.027 
Appendix 1

\begin{tabular}{|c|c|c|c|c|c|c|}
\hline \multicolumn{2}{|c|}{$\begin{array}{l}\text { Read the statements below carefully and } \\
\text { indicate how much you agree with each of } \\
\text { them }\end{array}$} & $\begin{array}{l}\text { I do } \\
\text { not } \\
\text { agree } \\
\text { at all }\end{array}$ & $\begin{array}{l}\text { I do not } \\
\text { agree }\end{array}$ & $\begin{array}{l}\text { Neither } \\
\text { disagree nor } \\
\text { agree }\end{array}$ & I agree & $\begin{array}{l}\text { I } \\
\text { completely } \\
\text { agree }\end{array}$ \\
\hline \multicolumn{7}{|c|}{ Brand Loyalty } \\
\hline BL1 & $\begin{array}{l}\text { Customers can find and purchase our } \\
\text { products/services }\end{array}$ & 1 & 2 & 3 & 4 & 5 \\
\hline BL2 & $\begin{array}{l}\text { Customers have an interactive, } \\
\text { creative experiences with our brand }\end{array}$ & 1 & 2 & 3 & 4 & 5 \\
\hline BL3 & $\begin{array}{l}\text { Customers can share } \\
\text { review of our products/services } \\
\text { with other customers through all } \\
\text { channels }\end{array}$ & 1 & 2 & 3 & 4 & 5 \\
\hline BL4 & $\begin{array}{l}\text { Customers are willing to pay a higher } \\
\text { price for our brand over other brands }\end{array}$ & 1 & 2 & 3 & 4 & 5 \\
\hline \multicolumn{7}{|c|}{ Customer and Prices } \\
\hline CP1 & $\begin{array}{l}\text { We have established reasonable prices } \\
\text { for the offered products/services }\end{array}$ & 1 & 2 & 3 & 4 & 5 \\
\hline $\mathrm{CP} 2$ & $\begin{array}{c}\text { We offer good value for the price we } \\
\text { set }\end{array}$ & 1 & 2 & 3 & 4 & 5 \\
\hline CP3 & $\begin{array}{l}\text { We use special offers to raise a } \\
\text { customer's } \\
\text { interest and influence the purchase } \\
\text { of our products/services versus } \\
\text { competitors' product }\end{array}$ & 1 & 2 & 3 & 4 & 5 \\
\hline CP4 & $\begin{array}{l}\text { Our prices are the same offline as } \\
\text { well as online }\end{array}$ & 1 & 2 & 3 & 4 & 5 \\
\hline \multicolumn{7}{|c|}{ Customer retention } \\
\hline CR1 & $\begin{array}{c}\text { We have a loyalty card that provides } \\
\text { exclusive discounts and enables our } \\
\text { customers to come back and } \\
\text { purchase again }\end{array}$ & 1 & 2 & 3 & 4 & 5 \\
\hline CR2 & $\begin{array}{l}\text { The atmosphere inside the retail } \\
\text { store is always pleasant }\end{array}$ & 1 & 2 & 3 & 4 & 5 \\
\hline CR3 & $\begin{array}{l}\text { Sensitivity to the environment and } \\
\text { social responsibility activities } \\
\text { contribution to the corporate image } \\
\text { are important in terms of customer } \\
\text { retention }\end{array}$ & 1 & 2 & 3 & 4 & 5 \\
\hline CR4 & $\begin{array}{l}\text { In the case of online orders, the trust } \\
\text { that the customer's }\end{array}$ & 1 & 2 & 3 & 4 & 5 \\
\hline
\end{tabular}


INTERNATIONAL JOURNAL OF ACADEMIC RESEARCH IN BUSINESS AND SOCIAL SCIENCES

Vol. 11, No. 8, 2021, E-ISSN: 2222-6990 @ 2021 HRMARS

\begin{tabular}{|c|c|c|c|c|c|c|}
\hline & $\begin{array}{l}\text { product will be shipped is important } \\
\text { for the retention of customers. }\end{array}$ & & & & & \\
\hline \multicolumn{7}{|c|}{ Implementing traditional marketing as part of the engagement: } \\
\hline TM1 & $\begin{array}{l}\text { The retail store gives complete } \\
\text { information about brands, } \\
\text { promotions and services to its } \\
\text { consumers }\end{array}$ & 1 & 2 & 3 & 4 & 5 \\
\hline TM2 & $\begin{array}{l}\text { We provide adequate policy of } \\
\text { refunds and exchanges }\end{array}$ & 1 & 2 & 3 & 4 & 5 \\
\hline TM3 & $\begin{array}{l}\text { Our store maintains good } \\
\text { relationship with the Consumers by } \\
\text { sending greetings and special offers } \\
\text { on occasions }\end{array}$ & 1 & 2 & 3 & 4 & 5 \\
\hline TM4 & $\begin{array}{c}\text { We are present in traditional media } \\
\text { (such as TV, radio, newspapers, } \\
\text { magazines, flyer etc.) }\end{array}$ & 1 & 2 & 3 & 4 & 5 \\
\hline \multicolumn{7}{|c|}{ Implementing omnichannel marketing as part of the engagement: } \\
\hline OM1 & $\begin{array}{l}\text { Our store is present on most } \\
\text { social platforms with active } \\
\text { participation }\end{array}$ & 1 & 2 & 3 & 4 & 5 \\
\hline OM2 & $\begin{array}{l}\text { We have synergetic management of } \\
\text { the channels and customer touch } \\
\text { points geared toward optimizing the } \\
\text { holistic experience }\end{array}$ & 1 & 2 & 3 & 4 & 5 \\
\hline OM3 & $\begin{array}{c}\text { We frequently organize online } \\
\text { activities for stimulating the } \\
\text { customers to act }\end{array}$ & 1 & 2 & 3 & 4 & 5 \\
\hline OM4 & $\begin{array}{l}\text { Offering suggestions according to } \\
\text { customers' shopping preferences at } \\
\text { the online store is important for } \\
\text { customer engagement }\end{array}$ & 1 & 2 & 3 & 4 & 5 \\
\hline OM5 & $\begin{array}{c}\text { We regularly interact with } \\
\text { the customers and provides a good } \\
\text { customer care }\end{array}$ & 1 & 2 & 3 & 4 & 5 \\
\hline OM6 & $\begin{array}{l}\text { Increasing the amount of purchase } \\
\text { channels might create } \\
\text { sub-optimization and harmful } \\
\text { competition between us } \\
\text { var various channels } \\
\end{array}$ & 1 & 2 & 3 & 4 & 5 \\
\hline OM7 & $\begin{array}{l}\text { With our touchpoints we can trigger } \\
\text { full customer interaction }\end{array}$ & 1 & 2 & 3 & 4 & 5 \\
\hline
\end{tabular}


INTERNATIONAL JOURNAL OF ACADEMIC RESEARCH IN BUSINESS AND SOCIAL SCIENCES Vol. 11, No. 8, 2021, E-ISSN: 2222-6990 ㄷ 2021 HRMARS

\begin{tabular}{|l|l|l|l|l|l|l|}
\hline OM8 & $\begin{array}{l}\text { We are present trough all channels } \\
\text { Internet based media, such as social } \\
\text { networks, emails, websites, pop-up } \\
\text { dvertisement, mobile marketing et.) }\end{array}$ & 1 & 2 & 3 & 4 & 5 \\
\hline OM9 & $\begin{array}{c}\text { We provide seaming less experience } \\
\text { trough all online channels }\end{array}$ & 1 & 2 & 3 & 4 & 5 \\
\hline \multicolumn{7}{|c|}{ Customer buying process: } \\
\hline CB1 & $\begin{array}{l}\text { We adapt the selling behavior using } \\
\text { ffferent arguments depending on e } \\
\text { ach customer need and knowledge of } \\
\text { The product }\end{array}$ & 1 & 2 & 3 & 4 & 5 \\
\hline CB2 & $\begin{array}{c}\text { The employees of the retail are } \\
\text { efficient and reliable }\end{array}$ & 1 & 2 & 3 & 4 & 5 \\
\hline CB3 & $\begin{array}{c}\text { The brand reputation plays an } \\
\text { important role in the buying process } \\
\text { of the customers }\end{array}$ & 1 & 2 & 3 & 4 & 5 \\
\hline CB4 & $\begin{array}{c}\text { Our communication with our } \\
\text { customers is completely transparent } \\
\text { and honest }\end{array}$ & 1 & 2 & 3 & 4 & 5 \\
\hline
\end{tabular}

Second part - Personal Data

30. Gender

0)Male

1)Female

31. Age

1) below 20 years old

2) $20-29$

3) $30-39$

4) $40-49$

5) above 50 years old

32. Level of education

0) Middle school

1) High School

2)Specialized High School

3) Bachelor's Degree

4) Master's Degree

5) Ph.D.

years

33. What is your position within the company?

0)C level

1) senior management

2)mid-level management

3) employee

34.What is the size of your company in terms of employees?

1) fewer than 10 employees

2)10 to 49 employees 
INTERNATIONAL JOURNAL OF ACADEMIC RESEARCH IN BUSINESS AND SOCIAL SCIENCES Vol. 11, No. 8, 2021, E-ISSN: 2222-6990 @ 2021 HRMARS

3)50 to 249 employees

4)+250 employees

35. Is marketing communication done internally or outsourced?
a) internally
b) outsourced

36.In what range is your company's annual revenue?

1)0-5million denars

2)5-10 million denars

3) 10 millions -1 billion denars

4)over 1 billion denars

37.What is the size of your company in terms of revenues?

1) Small Business

2) Medium-Small Business

3) Medium-Large Business

4) Large Enterprise

38. In what range is your company's annual net profit margin?

0) 0-1.000.000 denars

1) $1.000 .001-5.000 .000$ denars

2) 5.000.001-10.000.000 denars

3) 10.000.000-20.000.000 denars

4) 20.00.001-30.000.000 denars

5) 30.000.001-40.000.000 denars

6) 40.000.001-50.000.000 denars

7) Over 50.000 .000 denars 


\section{Appendix 2}

Table 1 Distribution of demographic variables

\begin{tabular}{|c|c|c|}
\hline & Values & $\%(N=100)$ \\
\hline \multirow{2}{*}{ Gender } & Male & 55 \\
\hline & Female & 45 \\
\hline \multirow{5}{*}{ Age (years) } & Below 20 & 0 \\
\hline & $20-29$ & 5 \\
\hline & $30-39$ & 37 \\
\hline & $40-49$ & 42 \\
\hline & $50+$ & 16 \\
\hline \multirow{4}{*}{ Education } & $\begin{array}{l}\text { Specialized High } \\
\text { School }\end{array}$ & 5 \\
\hline & Bachelor's Degree & 37 \\
\hline & Master's Degree & 42 \\
\hline & Ph. D. & 16 \\
\hline \multirow{3}{*}{$\begin{array}{l}\text { Position in } \\
\text { Company }\end{array}$} & $\begin{array}{c}\text { Senior } \\
\text { Management }\end{array}$ & 34 \\
\hline & $\begin{array}{c}\text { Mid-level } \\
\text { Management }\end{array}$ & 62 \\
\hline & Employee & 4 \\
\hline \multirow{4}{*}{$\begin{array}{l}\text { Time with } \\
\text { Company }\end{array}$} & 1 & 7 \\
\hline & 2 & 28 \\
\hline & 3 & 30 \\
\hline & 4 & 35 \\
\hline \multirow{4}{*}{$\begin{array}{l}\text { Number of } \\
\text { employees }\end{array}$} & $<10$ & 4 \\
\hline & $10-49$ & 38 \\
\hline & $50-249$ & 41 \\
\hline & $250+$ & 17 \\
\hline \multirow{4}{*}{ Business size } & Small & 23 \\
\hline & Medium-small & 26 \\
\hline & Medium-large & 17 \\
\hline & Large & 30 \\
\hline \multirow{2}{*}{$\begin{array}{c}\text { Marketing } \\
\text { Communication } \\
\text { Management }\end{array}$} & Internal & 37 \\
\hline & Outsourced & 63 \\
\hline \multirow{4}{*}{ Annual Revenue } & 0-5million denars & 18 \\
\hline & 5-10 million denars & 51 \\
\hline & $\begin{array}{l}10 \text { million }-1 \\
\text { billion denars }\end{array}$ & 20 \\
\hline & $\begin{array}{l}\text { over } 1 \text { billion } \\
\text { denars }\end{array}$ & 11 \\
\hline \multirow{5}{*}{$\begin{array}{c}\text { Annual Net Profit } \\
\text { Margin }\end{array}$} & 0-1million & 15 \\
\hline & 1-5million & 27 \\
\hline & 5-10million & 25 \\
\hline & 10-20million & 16 \\
\hline & Over 10 million & 17 \\
\hline
\end{tabular}


Figure 1 Responses to Brand Loyalty Subscale. Agreement ranged from I do not agree at all (1) to I completely agree (5).

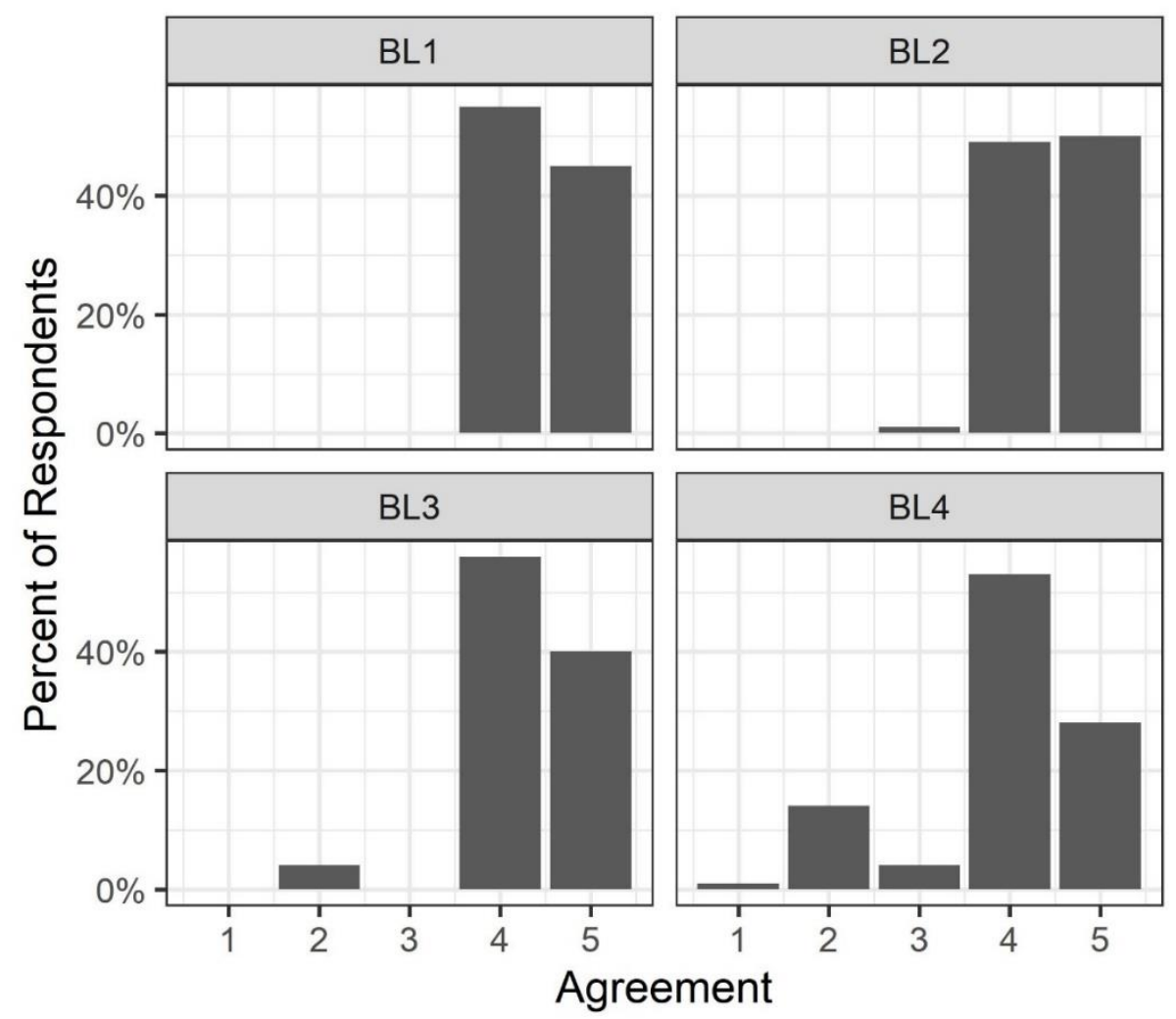

Figure 2 Responses to Customer and Prices. Responses to Brand Loyalty Subscale. Agreement ranged from I do not agree at all (1) to I completely agree (5).

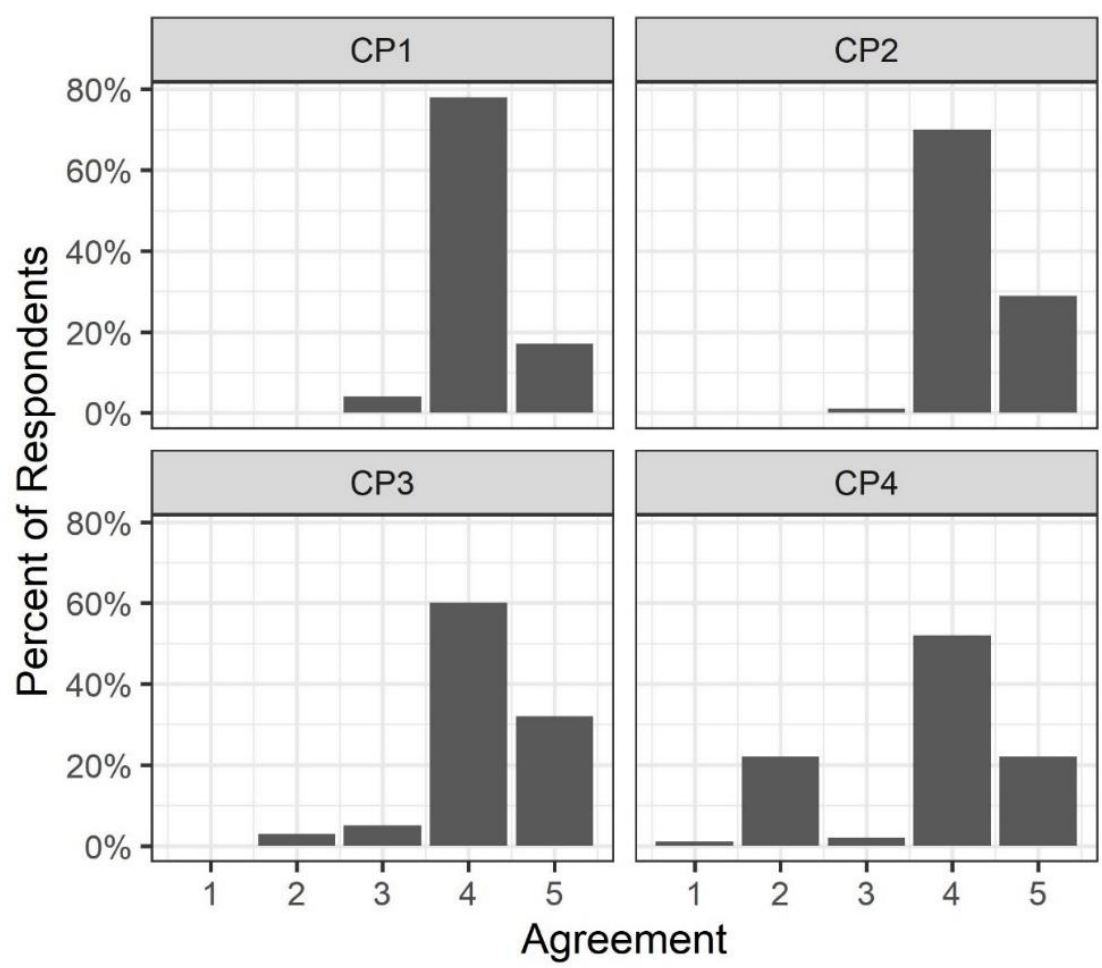


Figure 3 Responses to Customer Retention. Responses to Brand Loyalty Subscale. Agreement ranged from I do not agree at all (1) to I completely agree (5).

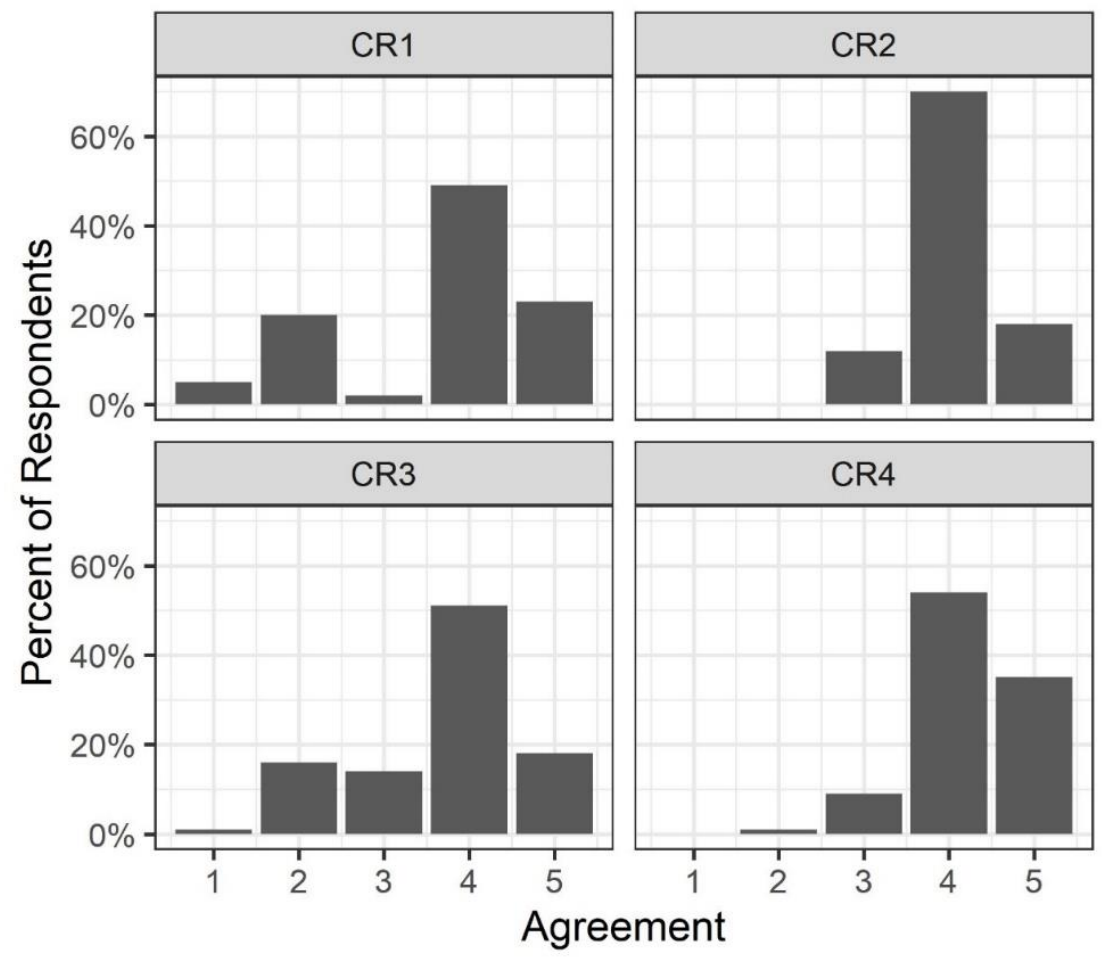

Figure 4 Responses to Implementing Traditional Marketing. Responses to Brand Loyalty Subscale. Agreement ranged from I do not agree at all (1) to I completely agree (5).

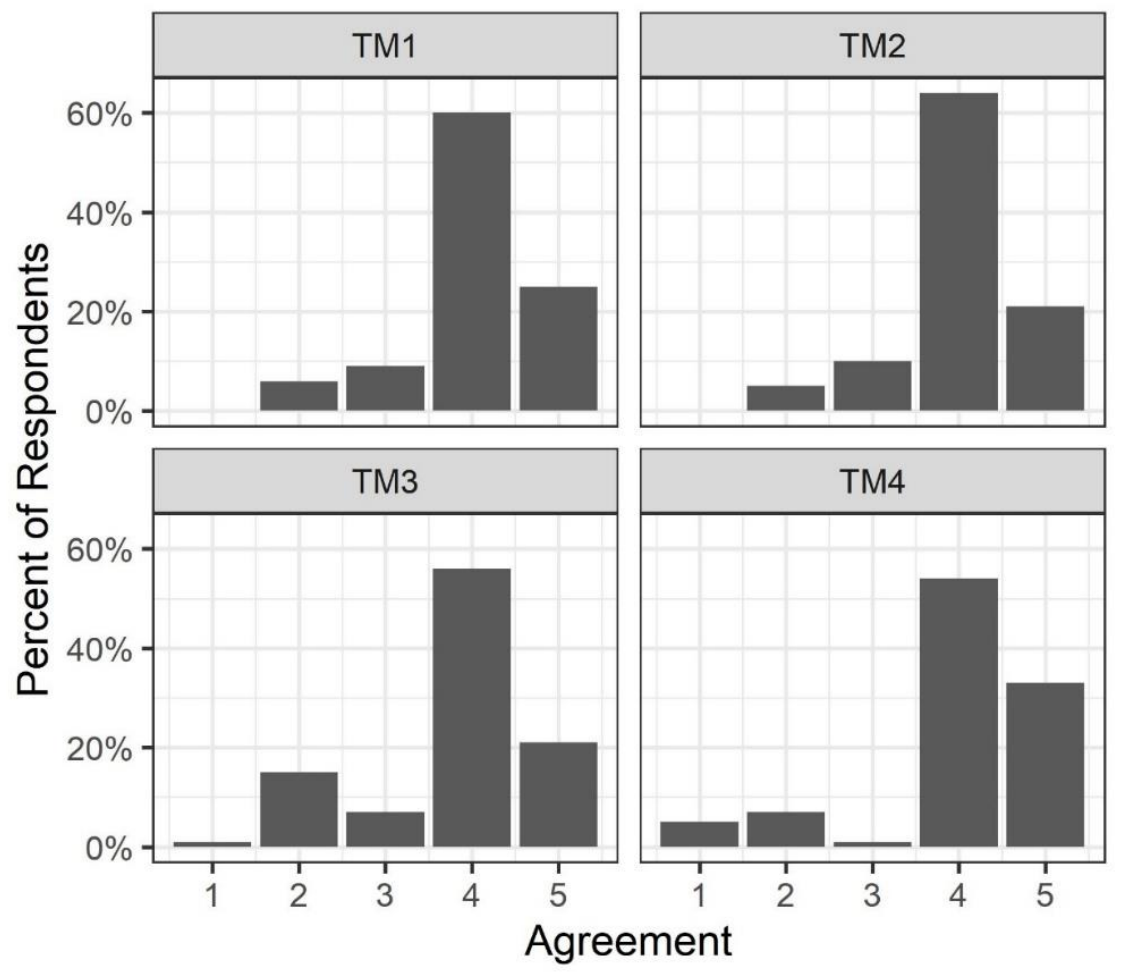


Figure 5 Response to Customer Buying Process. Responses to Brand Loyalty Subscale. Agreement ranged from I do not agree at all (1) to I completely agree (5).

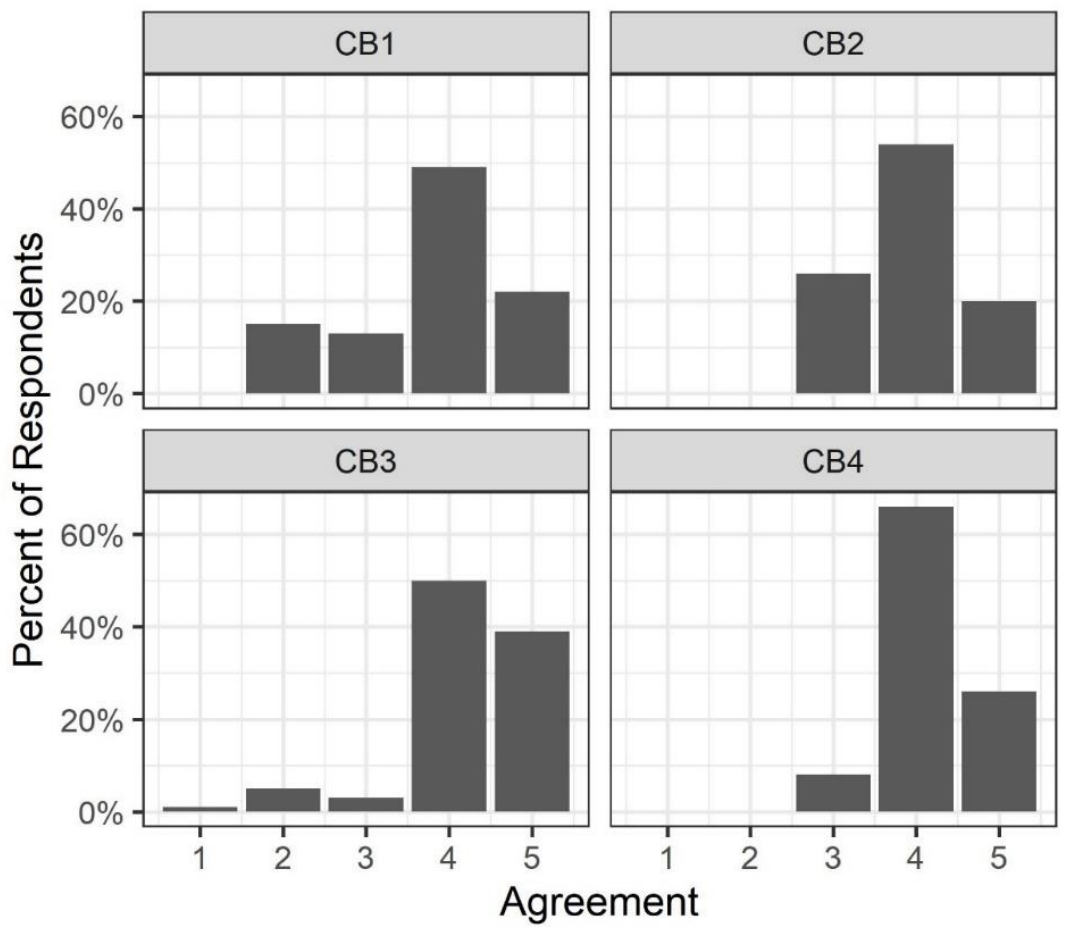

Figure 6 Responses to Implementing Omnichannel Marketing. Responses to Brand Loyalty Subscale. Agreement ranged from I do not agree at all (1) to I completely agree (5).

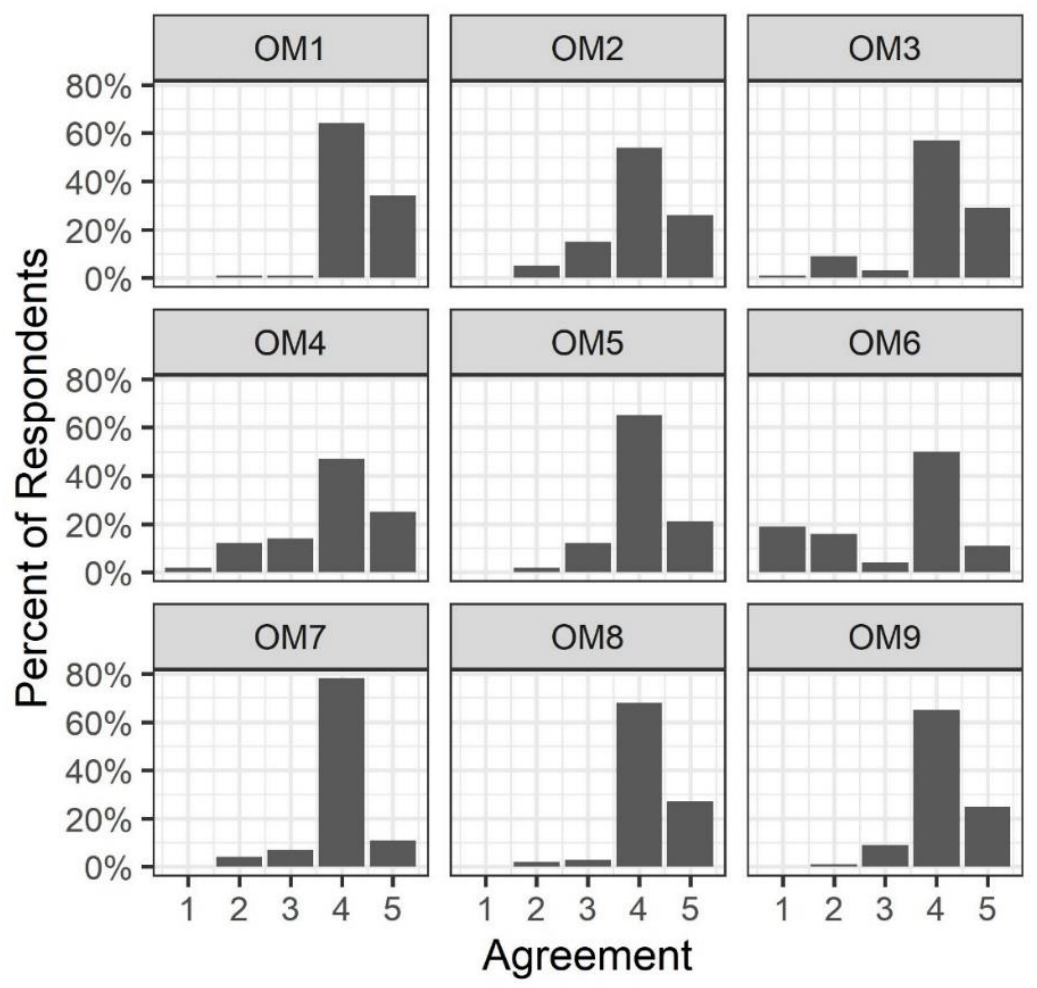


Figure 7 Scree Plot of Parallel Analysis for Omnichannel Marketing. The distance between the simulated, resampled, and actual data is minimal at the fourth factor, suggesting this to be the ideal number of factors to extract. ).

\section{Parallel Analysis Scree Plots}

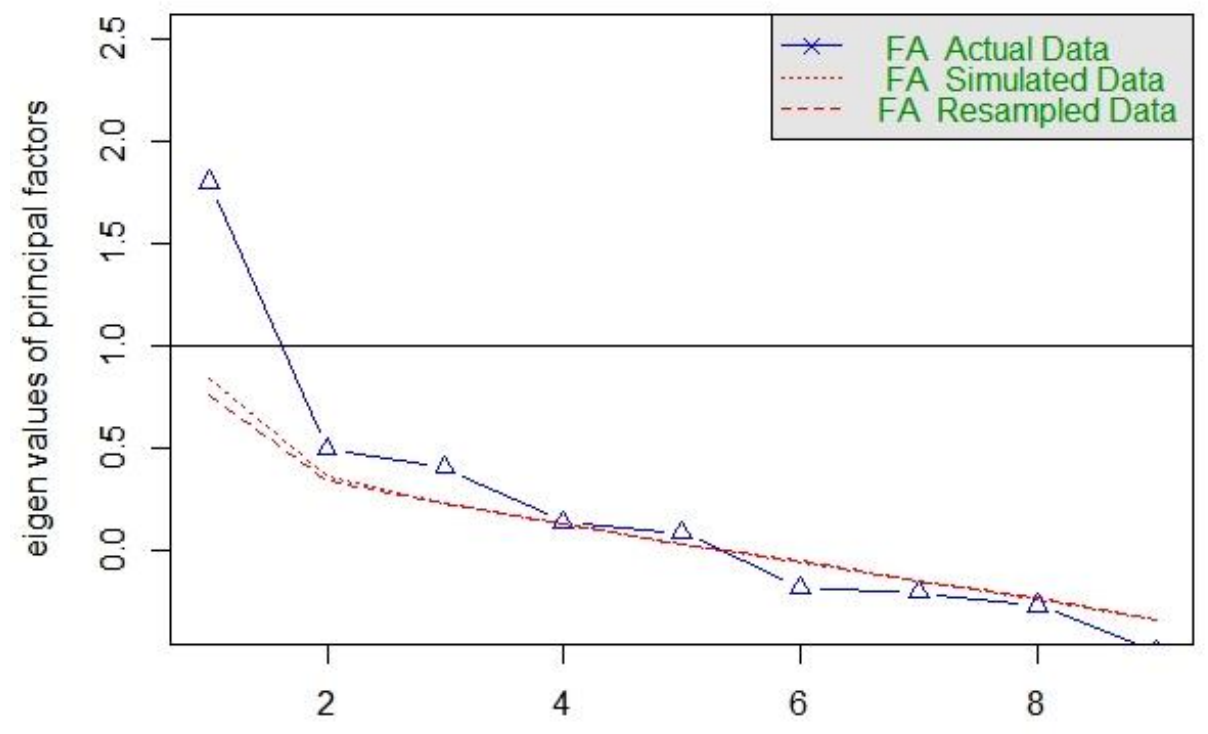

Factor Number

Table 2 Factor Loadings for Omnichannel Marketing.

\begin{tabular}{ccccc}
\hline & $\begin{array}{c}\text { Multiple } \\
\text { Online } \\
\text { Presence }\end{array}$ & $\begin{array}{c}\text { Synergized } \\
\text { Online } \\
\text { Activities }\end{array}$ & $\begin{array}{c}\text { Responding to } \\
\text { Customer } \\
\text { Suggestions }\end{array}$ & $\begin{array}{c}\text { Purchase } \\
\text { Channels }\end{array}$ \\
\hline OM7 & 0.425 & & & \\
OM8 & 0.982 & & & \\
OM9 & 0.487 & 0.757 & & \\
\hline OM1 & & 0.604 & 0.989 & \\
OM2 & 0.347 & 0.335 & 0.363 \\
OM3 & & & 1.132 & 0.066 \\
\hline OM5 & & & & \\
\hline OM4 & 1.280 & 0.126 & 0.494 \\
OM6 & 1.433 & 0.142 & & \\
\hline SS Loadings & & & & \\
\hline $\begin{array}{c}\text { Proportion } \\
\text { Variance }\end{array}$ & 0.159 & 0.301 & & \\
Explained & & & & \\
\hline $\begin{array}{c}\text { Cumulative } \\
\text { Variance } \\
\text { Explained }\end{array}$ & 0.159 & & & \\
\hline
\end{tabular}


Figure 8 Scratterplots of company performance against customer engagement. Annual net profit (A.N.P) and annual revenue (A.R.) are each correlated with Customer Engagement (CE) and Omnichannel Marketing (OM).
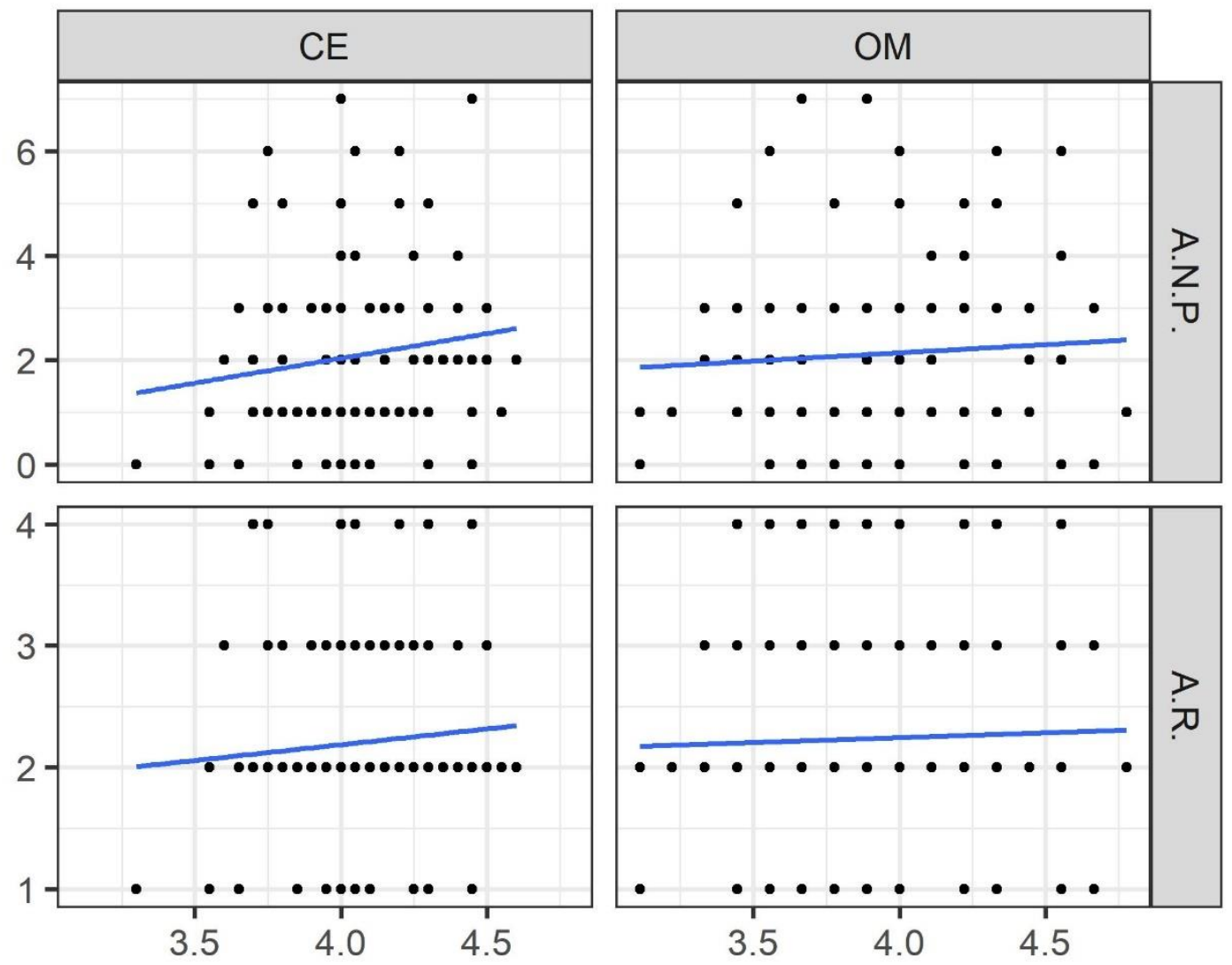

Table 3 Multiple Regression results test for moderation effect of omnichannel marketing on the relationship between customer engagement and company annual revenue

\begin{tabular}{lllll}
\hline & Estimate & Std. Error & T-value & p-value \\
\hline $\begin{array}{l}\text { Intercept } \\
\text { Customer }\end{array}$ & -1.5764 & 15.7219 & -0.100 & 0.920 \\
$\begin{array}{l}\text { Engagement } \\
\text { Omnichannel }\end{array}$ & 0.8492 & 3.8704 & 0.219 & 0.827 \\
$\begin{array}{l}\text { Marketing } \\
\begin{array}{l}\text { Cust. Eng. } x \\
\text { Omni. Market. }\end{array}\end{array}$ & -0.1640 & 3.9635 & 0.190 & 0.850 \\
\hline
\end{tabular}


INTERNATIONAL JOURNAL OF ACADEMIC RESEARCH IN BUSINESS AND SOCIAL SCIENCES Vol. 11, No. 8, 2021, E-ISSN: 2222-6990 @ 2021 HRMARS

Table 4 Multiple Regression results test for moderation effect of omnichannel marketing on the relationship between customer engagement and company annual net profit.

\begin{tabular}{lllll}
\hline & Estimate & Std. Error & T-value & p-value \\
\hline Intercept & -24.14 & 34.059 & -0.803 & 0.424 \\
$\begin{array}{l}\text { Customer } \\
\text { Engagement }\end{array}$ & 6.337 & 7.4 & 0.856 & 0.394 \\
$\begin{array}{l}\text { Omnichannel } \\
\text { Marketing }\end{array}$ & 5.738 & 7.578 & 0.757 & 0.451 \\
$\begin{array}{l}\text { Cust. Eng. x } \\
\text { Omni. Market. }\end{array}$ & -1.378 & 1.853 & -0.743 & 0.459 \\
\hline
\end{tabular}

$F(3,88)=0.878, p=0.455$

$R^{2}=0.0290$ 